\title{
Microalgae Water Bioremediation: Trends and Hot Topics
}

\author{
Diana Pacheco ${ }^{1, *}$, Ana Cristina Rocha ${ }^{1}$ (), Leonel Pereira ${ }^{1,2, *}$ and Tiago Verdelhos ${ }^{1,2}$ \\ 1 Marine and Environmental Sciences Centre (MARE-UC), Incubadora de Empresas da Figueira da Foz, \\ Parque Industrial e Empresarial da Figueira da Foz (Laboratório MAREFOZ), Rua das Acácias Lote 40A, \\ 3090-380 Figueira da Foz, Portugal; acsrocha@uc.pt (A.C.R.); tverdelhos@ci.uc.pt (T.V.) \\ 2 Department of Life Sciences, Faculty of Sciences and Technology, University of Coimbra, \\ 3000-456 Coimbra, Portugal \\ * Correspondence: dianampacheco96@gmail.com (D.P.); leonel.pereira@uc.pt (L.P.)
}

Received: 30 January 2020; Accepted: 7 March 2020; Published: 10 March 2020

\begin{abstract}
The need to reduce costs associated with the production of microalgae biomass has encouraged the coupling of process with wastewater treatment. Emerging pollutants in municipal, industrial, and agricultural wastewaters, ranging from pharmaceuticals to metals, endanger public health and natural resources. The use of microalgae has, in fact, been shown to be an efficient method in water-treatment processes and presents several advantages, such as carbon sequestration, and an opportunity to develop innovative bioproducts with applications to several industries. Using a bibliometric analysis software, SciMAT, a mapping of the research field was performed, analyzing the articles produced between 1981 and 2018, aiming to identifying the hot topics and trends studied until now. The application of microalgae on water bioremediation is an evolving research field that currently focuses on developing efficient and cost-effective treatments methods that also enable the production of add-value products, leading to a blue and circular economy.
\end{abstract}

Keywords: bibliometric analysis; microalgae; water bioremediation; algal biotechnology

\section{Introduction}

Water quality is a fundamental concern of the present century, considering the increasing scarcity of water resources. Degradation of water quality, either caused by anthropogenic activities (e.g., pollution; resources overexploitation) or natural phenomena (e.g., global warming; extreme climatic events) often leads to severe impacts on ecosystems, public health and economic growth, negatively affecting society and environment [1]. The improvement of water quality is a central issue included in the 2030 Agenda and on Sustainable Development Goals, recognizing the importance of good-quality water for a sustainable development of society and, therefore, the need to globally address this problem.

The discharge of untreated or inadequately treated effluents into rivers, lakes, aquifers and coastal waters supplies the aquatic environment with a myriad of chemical compounds that can impact aquatic organisms directly, by triggering hazardous effects, and indirectly, by changing some physicochemical features of the medium (e.g., oxygen concentration, $\mathrm{pH}$, redox potential and nutrient concentration) $[2,3]$.

Contaminants often result from domestic, agricultural and industrial effluents and their physical and chemical compositions differ according to their origins [4]. The most frequently found are metals [5], pesticides [6] and nutrients, such as nitrate [7] and phosphate [8]. Moreover, the occurrence of emerging organic and inorganic pollutants, such as microplastics [9], pharmaceuticals [10], flame retardants [11], personal care products [12], hazardous and noxious substances [13] has been increasing 
since conventional wastewater treatment plants (WWTP) are not yet equipped and suitable to remove these new contaminants.

The complexity of effluent composition is increasing as human activities intensify, so it is urgent to develop adequate wastewater treatment processes, which should be easily applicable, effective and eco-friendly, in order to prevent water quality degradation and to protect water resources.

Physicochemical processes alone are proven to be inefficient regarding the treatment of effluents with complex composition [11]. A possible solution can be the combination of physicochemical and biological treatment technologies aiming at the development of sustainable treatment processes.

Biological treatments often involve the cultivation of microalgae. The capacity of microalgae to remove nutrients [14], metals [4], pharmaceuticals [15,16], radioactive minerals [17] or pathogenic organisms [18] from the medium has been highlighted in literature. Using microalgae to remove pollutants from wastewaters or effluents before their discharge or reutilization is named phycoremediation [6]. The basic mechanism behind this process is inherent to the algal metabolism, nevertheless, the removal of pollutants will be variable accordingly to different microalgae used and effluents' characteristics.

Therefore, the design of the cultivation system is a critical parameter for microalgae production in order to achieve optimal growth rates and minimize costs [19]. For microalgae production, several factors are important to take into account, namely, the biology of the microalgae, cultivation land area, light, nutrient supply, labor, energy, carbon dioxide, $\mathrm{pH}$, temperature and the type of the final product [20-22].

Several methodologies of microalgae production have been developed over time, from laboratorial systems under accurate controlled conditions, to open systems in the field under natural, uncontrolled and unpredictable conditions [20]. Table 1 summarizes the main systems, methods and strategies used. Microalgae are typically cultivated in open or closed culture systems. Furthermore, diverse strategies, namely in batch, continuous and semi-continuous, are applied around the world and which differ mainly on nutrient supply and operation modes [20].

Due to the high energy demand and operation costs of harvesting processes, solutions were investigated in order to simplify this process [23]. Therefore, new methods of microalgae cultivation, like the immobilization method on alginate beads and the development of bioreactors that use microalgae biofilm, have emerged and have been coupled to the treatment of wastewater [24,25]. Also, the biological interactions among microalgae and bacteria or fungi and microalgae's ability to naturally flocculate under adverse conditions are under study as means to increase microalgae biomass productivity $[26,27]$ and to reduce harvesting [28], respectively.

Phycoremediation shows great potential to complement traditional wastewater treatment processes. Microalgae cultivation is, thus, a promising approach for WWTP in municipalities or industries, promoting environmentally sustainable effluent treatment, and nutrient and carbon biosequestration; and yields economic benefits-cost reduction and revenue from innovative products originated from microalgae (e.g.,: pigments, enzymes, sugars, and lipids) [6]. Furthermore, this approach addresses the need to reduce the costs associated with microalgae biomass production [29], through the recycling of wastewater to obtain microalgal biomass instead of culture medium [26]. Nowadays, there are already several cases of enterprises worldwide using wastewater sources for microalgae production: United States-Algae Systems and Sundine Enterprises, Inc.; United Kingdom-I-PHYC; Australia-Algae Enterprises; Israel-Aquonos Energy Ltd. [4,30].

Microalgae have indeed gained attention from the scientific community and have been a growing subject in research and development (R\&D) or research and technology development (R\&TD) studies and projects over the last decades, mainly focused on their resilience to grow on different types of wastewaters, performing phycoremediation and promoting decarbonization [31]. 
Table 1. Summary of different systems, methods and strategies of microalgae cultivation commonly used.

\begin{tabular}{ll}
\hline Microalgae Cultivation & Description \\
\hline System & $\begin{array}{c}\text { Ponds, tanks, lakes and raceway ponds are examples of open culture systems. } \\
\text { These outdoor systems were the first and are the most used for large-scale } \\
\text { production of microalgae biomass due to their simple construction, easy } \\
\text { operation and low energy demands [32]. However, open culture systems not } \\
\text { only are affected by climate conditions and exterior contamination as they also } \\
\text { show low productivity and loss of nutrients by evaporation [33]. }\end{array}$ \\
$\begin{array}{c}\text { Closed systems are usually denominated by photobioreactors and are } \\
\text { characterized by not allowing exchanges between the microalgae culture and } \\
\text { the external environment [20], presenting different designs, such as tubular, } \\
\text { plastic bags, flat-plate and bubble-column [34]. Closed-culture systems } \\
\text { overcome some of the challenges faced by open systems, such as higher } \\
\text { productivity, less nutrient evaporation and contamination [35]. Nevertheless, } \\
\text { these systems present a high energy demand, being their implementation }\end{array}$
\end{tabular}
expensive [34].

\begin{tabular}{|c|c|}
\hline \multicolumn{2}{|l|}{ Method } \\
\hline Co-Culture Method & $\begin{array}{l}\text { Microalgae exist in nature as a part of a community, benefiting from the } \\
\text { interaction among microorganisms [36]. } \\
\text { In a co-culture method, more than one species is grown in the same medium, so } \\
\text { it should be taken into account that the species selected have similar growth } \\
\text { requirements [37]. Nowadays, co-culture of microalgae with yeast or bacteria } \\
\text { has shown potential to enhance the phycoremediation and biomass yield [26]. } \\
\text { In this cultivation method, microalgae synthesize higher contents of } \\
\text { exopolysaccharides to support the growth in hostile conditions [38]. }\end{array}$ \\
\hline Immobilized Method & $\begin{array}{l}\text { When compared with microalgae free-cell cultivation, the immobilization } \\
\text { process can overcome the biomass-harvesting challenge, ensuring that } \\
\text { metabolic substances can diffuse through the polymer gel matrix [39]. } \\
\text { Nevertheless, the costs of the polymer and the immobilization process, } \\
\text { accumulation of metabolic products and the efficiency of the bioremediation are } \\
\text { some of the drawbacks of this cultivation method [6]. Still, previous studies } \\
\text { show the potential of immobilized microalgae in wastewater bioremediation } \\
\text { and metal recovery [40]. }\end{array}$ \\
\hline \multicolumn{2}{|l|}{ Strategy } \\
\hline Batch & $\begin{array}{l}\text { This is a simple closed system and low-cost strategy, since it does not require } \\
\text { much control. This strategy is characterized by no renewal of culture medium, } \\
\text { so the microalgae culture grows until it reaches the decline phase [20]. In } \\
\text { practice, the culture could crash for several reasons such as nutrient or oxygen } \\
\text { depletion, self-shading, pH variations or contamination [41]. }\end{array}$ \\
\hline Semi-Continuous & $\begin{array}{l}\text { This strategy is like a batch system but, in this case, the culture medium is } \\
\text { renewed periodically, while effluent is removed at the same time [20]. } \\
\text { Nevertheless, this strategy could not be appropriate for microalgae cultivation } \\
\text { because light is a limiting-factor that affects biomass productivity [ } 42 \text { ]. }\end{array}$ \\
\hline Continuous & $\begin{array}{l}\text { A continuous strategy that consists in the constant renewal of growth medium, } \\
\text { in which the volume of culture medium that is supplemented is the same as the } \\
\text { volume of culture that is removed [20]. The advantage of continuous renewal of } \\
\text { medium is the achievement of high biomass productivity [43]. Also, it is easy to } \\
\text { scale-up for industrial microalgae production due to the simple operation of the } \\
\text { cultivation system [44]. }\end{array}$ \\
\hline
\end{tabular}

Interest in this field of research is increasing related to the potential of microalgae cultivation for a circular economy, once the microalgal produced biomass can be used and valued in several industries (e.g., food, feed, textile, pharmaceutical, bioplastic, biofuel, biofertilizer and cosmetic $[33,45,46]$ ). Nevertheless, cost efficacy of commercialization is still an issue and essential to attract investors to 
up-scale production, so the technology is still being developed in terms of research and development [46]. Current research lines focus on four strategic alignments: feedstock, process, products, and market uptake $[30,47]$.

This review aims to point out trends and hot topics concerning the use of microalgae in wastewater treatment and to identify potential paths for future research regarding microalgae-based bioremediation. In order to achieve this goal, available literature will be mapped using a bibliometric tool to assess and analyze the topics that attracted more attention among the science community and their evolution through time.

\section{Methods}

An adequate bibliometric analysis is important to characterize and assess the evolution and dynamics of a research field. Nowadays, there are several software tools available for this type of analysis such as BibExcel, SCI-Map, VOSviewer, CiteSpace [48]. In this study, the used bibliometric tool was SciMAT-a new science mapping analysis software, presented in 2012-that aims to assess the topics that attracted more attention among the science community [49].

\subsection{Document Source Selection}

For this study, data were collected from the online database Web of Science, merely considering "article" type of document, from the period 1981 to 2018. The selected topic (TS) included the following combinations: TS $=($ "Microalgae $*$ And Bioremediation" $)$ OR TS $=($ "Microalgae*And Effluent" $)$ OR TS $=\left(\right.$ "Microalgae ${ }^{*}$ And Wastewater").

Since data collection and analysis were performed in 2019, this year was not included on this investigation due to data consistency. Using these search criteria, the study obtained 2942 articles that built the basis of this bibliometric analysis.

\subsection{Bibliometric Analysis}

In this bibliometric approach, two different analyses were performed to explore the application of microalgae in water bioremediation: an evaluation focused on scientific actors (researchers); and another on the influence of the scientific production on bibliographic data.

This allows the quantification and the visualization of sub-fields by key-words analysis [50]. Moreover, this methodology supports the visualization of general themes and its thematic evolution, based on a keyword and $h$-index analysis.

In this study, the software outputs presented a key-word analysis, which we considered to be representative of the research article. A deduplication process was also applied to improve data quality by grouping the concepts that represent the same ideas [51]. Then, to avoid flatness of the data, the years were divided into consecutive periods between 1981 and 2018, in particular: 1981-1990; 1991-2000; 2001-2010; 2011-2018.

\section{Bibliometric Performance Analysis}

\subsection{Publication Production}

Over the last half a century, the progressive increment of publications in this research area showed the increasing interest in the study and development of microalgae applications for water bioremediation. Figure 1 clearly exhibits such interest: from 1981 to 1990, only the publication of 5 articles were registered within this research field, but a significant increment was observed in the time frame between 1991 and 2000, with 109 article publications. This trend continued in the subsequent analyzed time periods (2001-2010 and 2011-2018), corresponding to 250 and 2578 articles published, respectively. Therefore, it should be expected that this increasing trend will continue. 


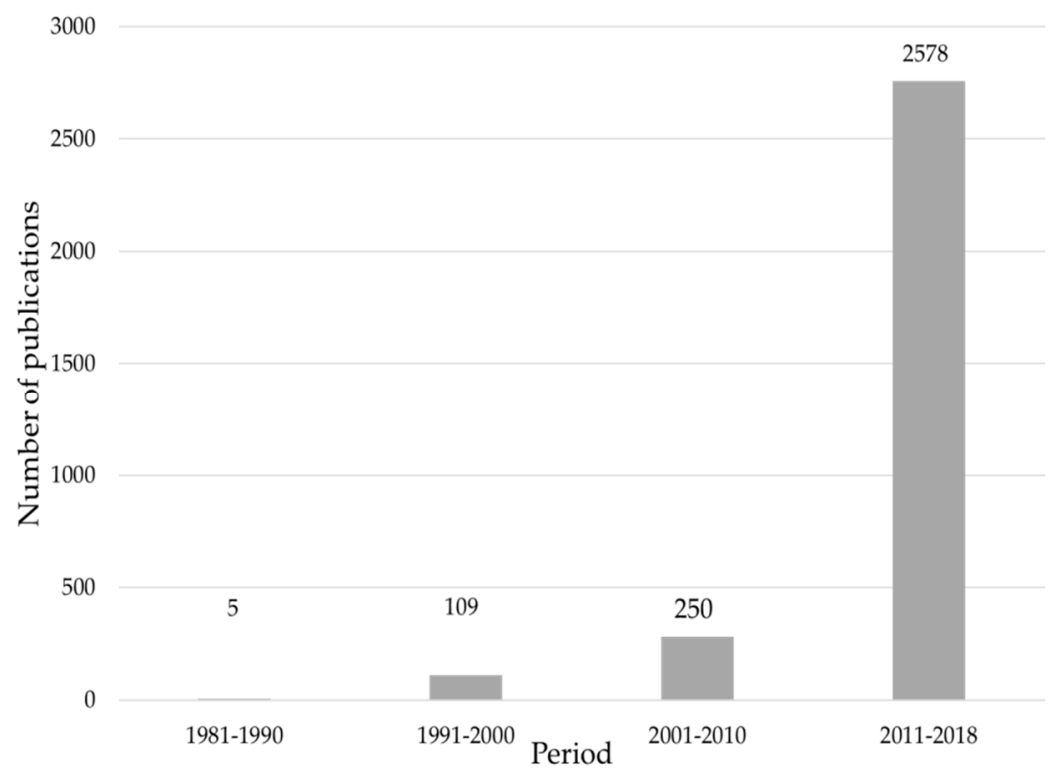

Figure 1. Number of articles published in each chosen period.

Within the period analyzed, several authors were quite prolific, producing a high number of publications and reaching high visibility and scientific impact. Table 2 summarizes the most productive authors according to the number of produced publications and $h$-index, which expresses the productivity of each author according to the impact of the publications.

Table 2. Most productive authors between 1981 and 2018.

\begin{tabular}{|c|c|c|c|c|}
\hline Author & $\begin{array}{c}\text { Number of } \\
\text { Publications }\end{array}$ & h-Index & Affiliation & Country \\
\hline Raul Muñoz & 44 & 53 & Valladolid University & Spain \\
\hline Joan García & 34 & 58 & Valencia University & Spain \\
\hline Roger Ruan & 32 & 60 & Minnesota University & USA \\
\hline Paul Chen & 27 & 53 & Minnesota University & USA \\
\hline Ivet Ferrer & 27 & 36 & Polytechnic University of Catalunya & Spain \\
\hline Jo-Shuo Chang & 26 & 89 & National Cheng Kung University & Taiwan \\
\hline S. Venkata Mohan & 26 & 71 & CSIR-Indian Institute of Chemical Technology & India \\
\hline Enrica Uggetti & 25 & 17 & Polytechnic University of Catalunya & Spain \\
\hline Byong-Hun Jeon & 24 & 44 & Hanyang University & South Korea \\
\hline Wenguang Zhou & 24 & 26 & Nanchang University & China \\
\hline
\end{tabular}

\subsection{Content Analysis}

The study regarding microalgae production and water bioremediation has focused on different themes over the years. The evolution maps resulting from the SciMAT analysis of 2942 published articles between 1981 and 2018 show the conceptual evolution and thematic areas throughout the periods analyzed through graphical interaction (Figure 2). Overall, analyzing the conceptual map, a growing interest in this research area seems quite clear, characterized by a progressive increment on the diversity of the investigated themes and the relationships between them. Here, the size of the spheres (Figure 2) represents the quantity of publications, while the thickness of the line represents the relationship between the themes [50]. 


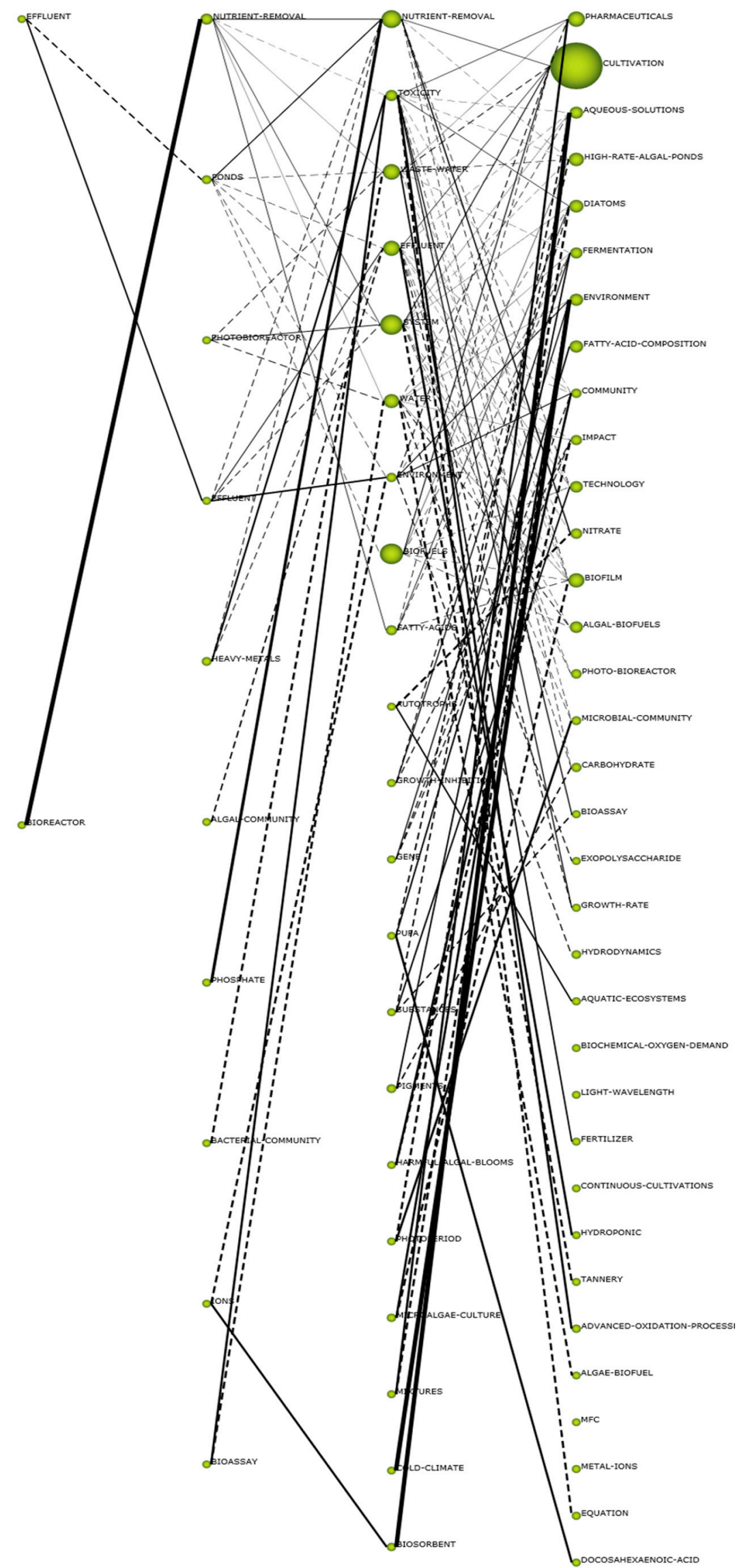

Figure 2. Evolution of thematic areas between 1981-2018 (SciMAT output). 
Specifically, between the periods 1981-1990 and 1991-2000, investigation focused on "bioreactors" and "nutrient-removal", these themes being strictly linked (Figure 2). In a closed system, the control of several parameters that affect microalgae growth and nutrient uptake is easier [41]. Moreover, the growth of kinetic models applied to microalgae growth and developed during this period was essential for recognizing nutrients, light and temperature as growth-limiting factors [52].

Research carried out on microalgae optimal growth conditions and restrictive factors was fundamental for the application of microalgae in water bioremediation. Non-optimal and stressful conditions of growth can induce metabolic responses in microalgae. For example, Nannochloropsis (Ochrophyta, Eustigmatophyceae) in nitrogen undernourishment conditions produce and accumulate high lipid content [23]. Therefore, the establishment of optimal growth conditions was pivotal. Successful growth of microalgae in closed systems has been achieved with high rates of nutrient removal, an important trait when considering water bioremediation. For instance, a study conducted with the microalgae Tetradesmus obliquus (formerly Scenedesmus obliquus) (Chlorophyta) demonstrated that, under a batch cultivation at $25^{\circ} \mathrm{C}$ in a cylindrical bioreactor, phosphorus and nitrogen removal rate was of $98 \%$ in $94 \mathrm{~h}$ and $100 \%$ in $188 \mathrm{~h}$, respectively, in urban wastewater [53].

Between the periods 1991-2000 and 2000-2010, the research themes were related to biotic and abiotic factors that could impair the application of water bioremediation technologies. Parameters such as temperature, $\mathrm{pH}$, oxygen, carbon and nutrient supply have a pivotal role in microalgae growth. Nevertheless, other factors can cause microalgae growth inhibition. Urban and industrial wastewaters generally present a complex composition with different types of inorganic and organic pollutants [4]. Such compounds can be toxic to microalgae, at certain concentrations, and inhibit their culture development. For this reason, a characterization of wastewater is important for understanding the composition of the effluent and foreseeing possible effects on the microalgae community. For instance, the growth of the microalgae Chlorella vulgaris (Chlorophyta) was inhibited in the presence of 400 $\mathrm{mg} / \mathrm{L}$ of phenol [54]. Nevertheless, at tolerable conditions, microalgae have also been shown to remediate pollutant-rich effluents [55-58]. Green microalgae Chlorella spp., T. obliquus (Chlorophyta) and Limnospira maxima (formerly Spirulina maxima) (Cyanobacteria) showed a capability to degrade organic compounds such as phenol $[55,56]$. Moreover, Auxenochlorella pyrenoidosa (formerly Chlorella pyrenoidosa), Chlamydomonas reinhardtii, and Stichococcus bacillaris (Chlorophyta) were shown to have more affinity to metal compounds such as iron $(\mathrm{Fe})$ and copper $(\mathrm{Cu})$ due to their importance as micronutrients to microalgae metabolism. Uptake rates of $70 \%$ and $98 \%$ of $\mathrm{Fe}$ and $\mathrm{Cu}$ were obtained after exposure of the mentioned species at $4 \mathrm{mg} / \mathrm{L}$ metal concentration [57]. Other microalgae, such as Tetraselmis marina, Stigeoclonium tenue and Spirogyra spp. (Chlorophyta), have shown potential to metal pollution bioremediation [59]. Apart from chemical toxicity, the removal of pollutants from effluents can be affected by several biotic factors, namely, the production of toxic compounds, enzyme induction, the composition of the microbial community and the number of microorganisms [11,26-28]. Therefore, it was important to address such issues in order to developed efficient remediation systems.

Apart from microalgae interaction with pollutants, the biological interactions among the bacterial-microalgal community have also been the target of study [26]. Bacteria produce extracellular polymeric substances that act as a bio-flocculation agent of the microalgae [59] which can be an advantage to overcome the harvesting of microalgae. In a swine effluent, co-culture of the bacteria Sphingobacteria, Flavobacteria, Terrimonas and Hyphomonas with the green microalgae C. vulgaris was shown to induce the formation of microalgal-bacteria aggregates. In this assay, a $94 \%$ flocculation activity, at a $\mathrm{pH} 11$, was registered within the co-culture of the mentioned microorganisms [60]. Furthermore, there is evidence that some microalgae species, like Phaeodactylum tricornutum (Bacillariophyta), also present the ability to flocculate as a response to several abiotic factors, such as light, $\mathrm{pH}$, temperature or carbon dioxide concentration [61,62].

Between the periods 2001-2010 and 2011-2018, the themes "cultivation", "wastewater", "nutrient removal" and "biofilms" were interconnected. One of the challenges of water bioremediation is the harvesting of microalgae, since traditional methods, such as centrifugation, are expensive and 
energy-demanding procedures. For this reason, in the last few years, there has been an increasing interest of the scientific community in developing different approaches and designs of bioreactors and methods of microalgae cultivation which tackle this need [63,64]. A new bioreactor design combined with a culture method-designated microalgae attachment was developed, namely, comprising microalgal cells attached to a substratum through the secretion of exopolysaccharides, producing a biofilm. In a nutrient-rich environment, such as wastewater, microalgae were shown to reproduce, augmenting the thickness of the biofilm $[65,66]$. Furthermore, a previous study had also revealed that a microalgae-bacteria consortium, attached on kenaf fibers as a substratum, was successful in removing nitrogen, phosphorous and atrazine (a toxic compound) from an effluent, registering removal rates of $91 \%, 85 \%$ and $84 \%$, respectively [67]. Herein, several features influencing water bioremediation with microalgae attachment must still be addressed, such as substratum properties and orientation, microalgal-bacteria community and interaction, environmental and operational conditions [65].

A liaison between the themes "pharmaceuticals" and "toxicity" was also found. Over the last few decades, pharmaceuticals have been detected in aquatic ecosystems [68], since current WWT seems unsuitable to remove them completely from effluents prior their discharge. Concerns with the environmental impact and threat to public health led to the development of several studies about the ability of microalgae to degrade such pollutants with toxic effect on the environment at low concentrations [17]. Literature reveals that microalgae can degrade pharmaceuticals $[15,16]$. For instance, Chlamydomonas oblonga (Chlorophyta) was exposed to $200 \mathrm{mg} / \mathrm{L}$ of an emergent contaminant, carbamazepine, a pharmaceutical used in the treatment of epilepsy, and a $30 \%$ growth inhibition and a $35 \%$ degradation rate of the pollutant was registered [69].

T. obliquus was shown to degrade salicylic acid, but presented different removal rates in batch culture and semi-continuous culture, achieving $93 \%$ and $99 \%$ of removal rate, respectively [68]. As mentioned before, several factors can influence the remediation of pharmaceutical-rich effluents. Therefore, it is important to take into consideration the strain selection, cultivation strategy, system and method to achieve the best bioremediation result.

The research themes studied during the selected period were evaluated and plotted in a strategic diagram. Research themes are characterized by density and centrality. Density assesses the internal strength of the network whereas centrality assesses the interaction of the network with other networks. Figure 3 shows the strategic diagrams obtained for each chosen period. In these plots, the themes are represented by spheres and the size of each sphere is representative of the number of articles and includes the number of citations [70]. Furthermore, in Figure 3, the most emphasized themes in the field of bioremediation with microalgae for each period are presented. The interpretation of these diagrams is generally focused on the quadrants [51]:

- Quadrant Q1: considered motor themes, important for the development of the research field.

- Quadrant Q2: themes well developed.

- Quadrant Q3: represents emergent or declining themes.

- Quadrant Q4: characterized by basic and transversal themes, nevertheless not well developed.

In the period 1981-1990 (Figure 3a), two research themes were identified-"effluent" and "bioreactor" — characterized by high centrality and density and, thus, considered important to the growth of the field of research. The first studies were developed in Thailand and focused on nutrient recycling, by promoting the growth of microalgae in Tilapia nilotica aquaculture effluents. A preliminary characterization of the microalgae community in the ponds showed that cyanobacteria and Euglena sp. (Euglenozoa) were the microalgae with higher occurrence [71]. Microalgae metabolized the nutrients present in the water and fish fed on microalgae, there being a recycling of nutrients. The optimal microalgae concentration in the ponds was, however, controlled to prevent negative impacts on fish cultivation [72]. The application of aquaculture effluent bioremediation aimed at addressing the issue of water scarcity by promoting a sustainable use of water resources through the reuse of water for fish cultivation and, subsequently, utilization of water for irrigation [73]. Studies focused on the presence 
of contaminants and pathogenic agents in recycled wastewater were reviewed by Emparan, Harun and Danquah (2019) [6].
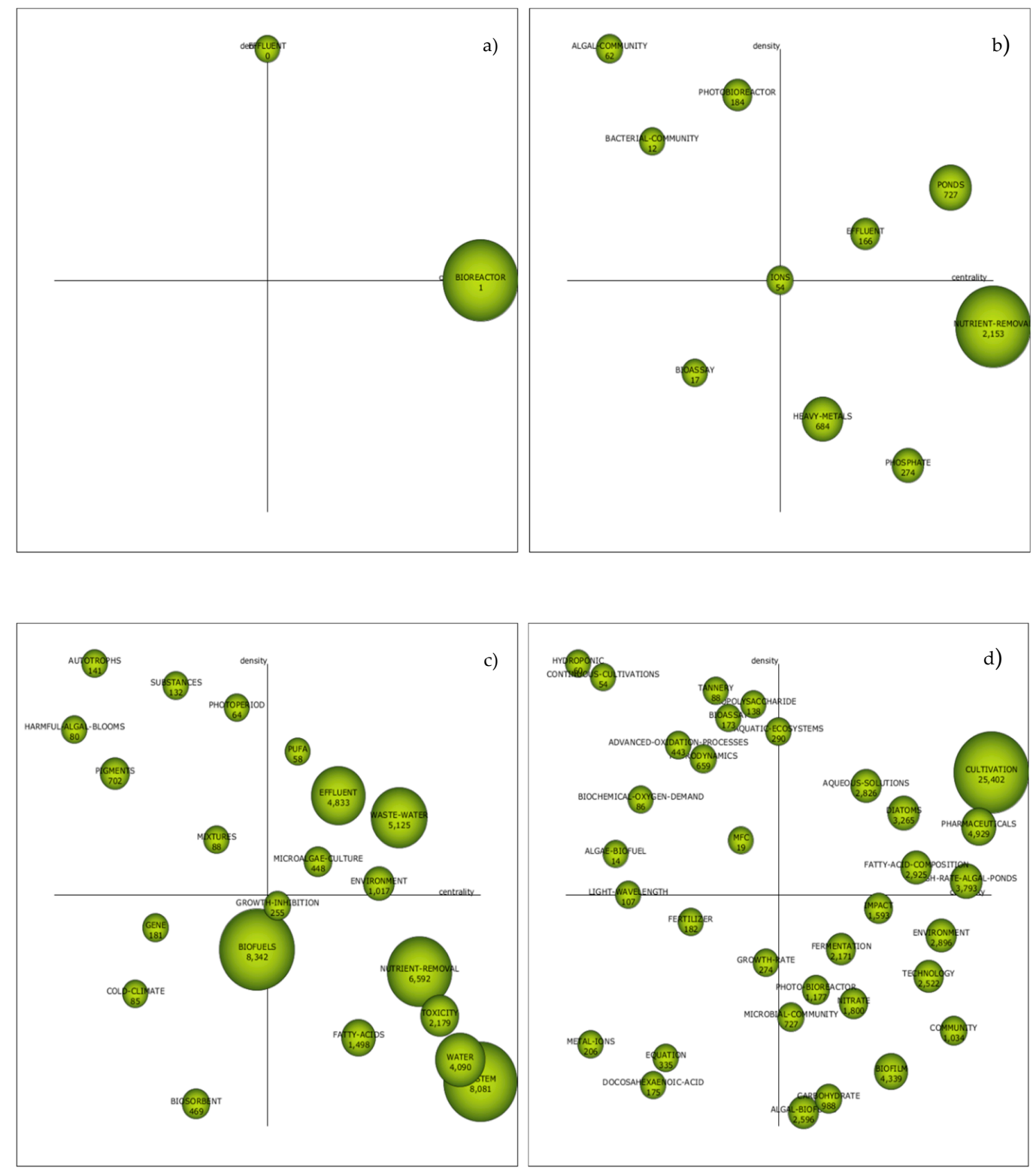

Figure 3. Strategic diagrams. (a) Period 1981-1990. (b) Period 1991-2000. (c) Period 2001-2010. (d) Period 2011-2018. (SciMAT output).

The Aquatic Species Program of research, funded by the United States Department of Energy's Office of Fuels Development, between 1980 and 1996, was a key-driver for the development of investigation on microalgae cultivation in open and closed systems aiming at the production of alternative fuels [74]. The main challenges addressed were the selection, isolation and maintenance of the microalgal strains, microalgae growth rate and operational conditions' optimization in order to produce biomass at a big scale and in a cost-effective way [44,75]. University of Berkeley applied an open raceway system in a deactivated wastewater treatment station, in Roswell, from 1988 to 1990, and obtained better results using native species collected from the wastewater and the surrounding environment [74]. Furthermore, research and technological advances in the design of bioreactors, within this period, were crucial for the development of water bioremediation technologies coupled with microalgae biomass production. American researchers hold several patents of photobioreactors 
for microalgae mass culture [76-78]. Photobioreactors allow a stricter control of biotic and abiotic parameters. However, for biofuel production, the application of this technology is not economically feasible due to the associated high energy demand and cost of technical operation [74].

In the period 1991-2000 (Figure 3b), 10 themes were identified, in which "effluent" and "ponds" were characterized as motor themes. Within this time frame, socio-economic interests regarding the scale-up of microalgae production focused scientific research on open culture systems and on the reduction of the costs of microalgae biomass production using wastewater as a growth medium. Microalgae metabolize nutrients such as carbon, nitrogen and phosphorous and use metals as micronutrients [79]. Carbon metabolization is needed to microalgae growth and cellular respiration [80] and nitrogen and phosphorous are processed to synthesize essential amino acids and DNA [49]. The literature produced also showed that microalgae have the potential to be used as a biosorbent agent for metal removal from wastewater. The polysaccharides present in microalgae's cell wall are responsible for metal adsorption, nevertheless, this adsorption ability depends on the species and growth conditions [81-85]. Furthermore, as previously mentioned, the success of bioremediation technologies using microalgae depends on their capacity to tolerate the pollutant concentration in the growth medium. Therefore, it is important to perform a preliminary characterization of the effluent and investigate, through toxicity bioassays the non-lethal concentrations of different pollutants for microalgae growth [57].

Between 2001-2010, 21 research themes were observed (Figure 3c), and the motor themes were: "fatty-acids", "effluent", "wastewater", "microalgae culture" and "environment". Microalgal biotechnology investigation was enhanced within this period and, initially, research focused on microalgae as a source of biofuels due to their fast growth [74]. On the other hand, nutrient pollution was a problem at a global scale and coupling biofuel production and microalgae growth in nutrient-rich effluents was pursued as a solution.

This problem should be handled through a multi-stakeholder cooperation [47] given its worldwide dimension. Within this context, the European Union (EU)-Japan Centre for Industrial Cooperation, a non-profit association whereby its mission is to promote the collaboration between Japan and the EU in order to provide partnerships and guidance to prepare projects related to microalgae application on water bioremediation, promoting a circular economy [30]. Furthermore, in 2003, the Japanese legal framework "Basic Act for the Establishment of a Sound Material Cycle Society" formulated a five-year plan in which the main goal was to use properly the natural resources and develop eco-friendly procedures for waste management while minimizing the harmful impacts on the environment. In this context, governmental institutions such as the New Energy and Industrial Technology Development Organization (NEDO) and the Ministry of Agriculture, Forestry and Fisheries (MAFF) supported several companies and universities as partners or facilitated funding opportunities [30]. This framework also launched the environmental goal of developing alternative WWT in detriment to the traditional WWT, aiming at nutrient recovery and recycling [84].

Furthermore, in the European Union, the Water Framework Directive, published in 2000, addresses and encourages the improvement of urban wastewater treatment with biological methods. More recently (2016), the Government of the Republic of Lithuania has, inclusively, approved a management plan in order to reduce the nutrient input in the Baltic Sea [47].

Microalgal biomass is a valuable resource with potential applications in several industries and is a key factor in the blue economy because of the value of its commercial applications and for being an alternative to land-based products or non-renewable resources. Hence, microalgae have gained increasing attention by the academia, industry and policy makers, especially since 2001.

In the last analyzed decade (2011-2018) (Figure 3d), the main motor-themes were: "cultivation", "aqueous-solution", "diatoms", "fatty-acids composition", "high rate algal-ponds" and "pharmaceuticals". Advances of more sensitive analytical equipment and methods led to the determination and identification of emerging water pollutants in aquatic ecosystems [85] resulting from human activities, such as pharmaceuticals, personal hygiene products, chemical cleaning agents 
and natural or synthetic hormones [86]. Under the scope of the European framework of the Water Directive and Wastewater Treatment Directive, numerous projects have been funded to overcome the challenge of water-emerging contaminants. Networks among reference laboratories, research centers and related organizations were created to monitor emerging environmental substances (NORMAN) and develop a database of geo-referenced monitoring and bio-monitoring data on emergent substances in water [87]. Studies regarding the use of microalgae as bioremediators of contaminated effluents were, as previously mentioned, conducted. Furthermore, ecotoxicological studies have been carried out with diatoms or other microalgae, which are primary producers and present higher sensitivity in the marine environment in comparison to other organisms [17]. The toxicological effects of fossil fuels [88], organophosphorus compounds [89] and polycyclic aromatic hydrocarbons [90], easily found in water, on microalgae were also studied. Nevertheless, some strains of microalgae were shown to be resilient with acclimatization capability through biochemical and physiological modifications [6].

High-rate algal ponds (HRAPs) have demonstrated feasibility at an operational and economical level for bioremediation of a secondary effluent from a wastewater treatment plant. Gentili and Fick (2017) obtained a $60 \%-80 \%$ and $60 \%-70 \%$ nitrogen $(\mathrm{N})$ and phosphorous $(\mathrm{P})$ removal, respectively, in a HRAP system [16]. Furthermore, a mixed freshwater population, in which Tetradesmus dimorphus (Chlorophyta) dominated, was shown to successfully grow in a HRAP system and to deplete different types of pharmaceuticals. Removal rates higher than $90 \%$ on pharmaceuticals, namely atenolol, atracurium, bisoprolol, bupropion, citalopram, diltiazem and metoprolol were reported [11,91].

The production of microalgal biomass into bioproducts is also a current theme of research and will promote the manufacture of innovative biological products as well as the creation of employment [47]. Photosynthetic microorganisms are efficient producers of high-value compounds, like polyunsaturated fatty acids (PUFAs) [92]. Studies showed that n-3 PUFAs have therapeutic properties, namely in cardiovascular and mental diseases [93]. Furthermore, it is important to characterize microalgae lipidic and protein content in order to understand the range of bio-products that can be developed. The protein and fatty-acids composition is distinctive among microalgae species, and factors like effluent physic and chemical characterization, aeration rate, temperature, photoperiod and light type and intensity, can influence the biochemical profiles of microalgae [94].

Within this scope, several funding opportunities have been created. For instance, the European Union has directed funds to support investigation within the field of bioeconomy given its social, economic and environmental impacts in the communities. The international project "Algae Service for LIFE" supported by LIFE Environment and Resource Efficiency sub-program aims to enhance good practices on ecosystem services and promote circular economy. Also, in Japan, the Agency for Natural Resources and Energy presented, in 2015, a report about the valorization of microalgal biomass from wastewater treatment processes [30]. Over the last decade, the United States Department of Agriculture (USDA) has supported several projects regarding wastewater bioremediation using microalgae aiming at water reutilization for agriculture purposes and as a measure against water scarcity [95].

\section{Conclusions}

The present study tracked the evolution of hot topics and trends, from 1981 to 2018, regarding the bioremediation of emergent pollutants and the characterization of the microalgal biomass with the purpose of developing innovative products. An environmental concern regarding water scarcity, water pollution and the restoration of aquatic ecosystems nourished the development of alternative methodologies of wastewater treatment over the last half a century. Moreover, the increasing interest in this research field, within the analyzed period, is also a reflection of the legislation developed and the funding opportunities created.

Microalgae can sequester carbon dioxide, remove nutrients, metals and organic contaminants and were proven to be suitable bioremediators of effluents. Nevertheless, several knowledge and application gaps still exist. Several biotic and abiotic parameters can influence microalgae growth and performance at removing contaminants, so methodologies' conditions must be established and be 
species-specific. Furthermore, it is also important to standardize optimal cultivation parameters along with harvesting techniques. Technologies for water treatment using microalgae are still currently under investigation, with the development of new photobioreactors in order to reduce the energetic costs associated. With regard to open systems, efforts are required to develop large-scale cultivation protocols to achieve practical applicability of microalgae cultivation and water bioremediation. Simultaneously, another important issue is the selection of naturally occurring high-yielding microalgae species.

Nowadays, the application of microalgae to wastewater or effluent bioremediation research has evolved and is focused on coupling bioremediation with the development of economically viable innovative bio-products, contributing to a circular economy and representing a multipurpose solution. Funding opportunities have, recently, been focused on the bioeconomy and the production of alternative bio-products which will boost the evolution of this research field.

Author Contributions: Conceive and design the idea: D.P., A.C.R., T.V. and L.P.; Writing and bibliographic research: D.P.; Bibliometric analysis: D.P.; Supervision and Manuscript Revision, A.C.R., T.V. and L.P. All authors have read and agreed to the published version of the manuscript.

Funding: This work was financed by national funds through FCT-Foundation for Science and Technology, I.P., within the scope of the project UIDB/04292/2020-MARE-Marine and Environmental Sciences Centre. Diana Pacheco thanks to PTDC / BIA-CBI / 31144/2017-POCI-01 project -0145-FEDER-031144-MARINE INVADERS, co-financed by the ERDF through POCI (Operational Program Competitiveness and Internationalization) and by the Foundation for Science and Technology (FCT, IP). Ana Cristina Rocha thanks to CENTRO2020-SAICT-Integrated Program, Operation CENTRO-01-0145-FEDER-000006, with the reference SAICT 000006 SUSpENsE- Sustainable built Environment under Natural Hazards and Extreme Events.

Conflicts of Interest: The authors declare no conflict of interest.

\section{References}

1. United Nations Educational, Scientific and Cultural Organization. International Initiative on Water Quality; United Nations Educational, Scientific and Cultural Organization: Paris, France, 2015.

2. Mohamad, S.; Fares, A.; Judd, S.; Bhosale, R.; Kumar, A.; Gosh, U.; Khreisheh, M. Advanced wastewater treatment using microalgae: Effect of temperature on removal of nutrients and organic carbon. In Conference Series: Earth and Environmental Science; Institute of Physics Publishing: Bristol, UK, 2017; Volume 67. [CrossRef]

3. Menger-Krug, E.; Niederste-Hollenberg, J.; Hillenbrand, T.; Hiessl, H. Integration of microalgae systems at municipal wastewater treatment plants: Implications for energy and emission balances. Environ. Sci. Technol. 2012, 46, 11505-11514. [CrossRef] [PubMed]

4. Wollmann, F.; Dietze, S.; Ackermann, J.U.; Bley, T.; Walther, T.; Steingroewer, J.; Krujatz, F. Microalgae wastewater treatment: Biological and technological approaches. Eng. Life Sci. 2019, 860-871. [CrossRef]

5. Chowdhury, S.; Mazumder, M.A.J.; Al-Attas, O.; Husain, T. Heavy metals in drinking water: Occurrences, implications, and future needs in developing countries. Sci. Total Environ. 2016, 569-570, 476-488. [CrossRef] [PubMed]

6. Emparan, Q.; Harun, R.; Danquah, M.K. Role of phycoremediation for nutrient removal from wastewaters: A review. Appl. Ecol. Environ. Res. 2019, 17, 889-915. [CrossRef]

7. Menció, A.; Mas-Pla, J.; Otero, N.; Regàs, O.; Boy-Roura, M.; Puig, R.; Bach, J.; Domènech, C.; Zamorano, M.; Brusi, D.; et al. Nitrate pollution of groundwater; all right ... , but nothing else? Sci. Total Environ. 2016, 539, 241-251. [CrossRef]

8. Schaum, C. Phosphorus: Polluter and Resource of the Future-Removal and Recovery from Wastewater. Water Intell. Online 2018, 17, 450-457. [CrossRef]

9. Eerkes-Medrano, D.; Leslie, H.A.; Quinn, B. Microplastics in drinking water: A review and assessment. Curr. Opin. Environ. Sci. Heal. 2019, 7, 69-75. [CrossRef]

10. Muñoz, I.; Gómez-Ramos, M.J.; Agüera, A.; Fernández-Alba, A.R.; García-Reyes, J.F.; Molina-Díaz, A. Chemical evaluation of contaminants in wastewater effluents and the environmental risk of reusing effluents in agriculture. TrAC Trends Anal. Chem. 2009, 28, 676-694. [CrossRef]

11. Sutherland, D.L.; Ralph, P.J. Microalgal bioremediation of emerging contaminants-Opportunities and challenges. Water Res. 2019, 164. [CrossRef] 
12. Norvill, Z.N.; Shilton, A.; Guieysse, B. Emerging contaminant degradation and removal in algal wastewater treatment ponds: Identifying the research gaps. J. Hazard. Mater. 2016, 313, 291-309. [CrossRef]

13. Wang, Y.; Ho, S.H.; Cheng, C.L.; Guo, W.Q.; Nagarajan, D.; Ren, N.Q.; Lee, D.J.; Chang, J.S. Perspectives on the feasibility of using microalgae for industrial wastewater treatment. Bioresour. Technol. 2016, 222, 485-497. [CrossRef] [PubMed]

14. Wang, J.H.; Zhang, T.Y.; Dao, G.H.; Xu, X.Q.; Wang, X.X.; Hu, H.Y. Microalgae-based advanced municipal wastewater treatment for reuse in water bodies. Appl. Microbiol. Biotechnol. 2017, 101, 2659-2675. [CrossRef] [PubMed]

15. Leng, L.; Wei, L.; Xiong, Q.; Xu, S.; Li, W.; Lv, S.; Lu, Q.; Wan, L.; Wen, Z.; Zhou, W. Use of microalgae based technology for the removal of antibiotics from wastewater: A review. Chemosphere 2020, 238, 124680. [CrossRef] [PubMed]

16. Gentili, F.G.; Fick, J. Algal cultivation in urban wastewater: An efficient way to reduce pharmaceutical pollutants. J. Appl. Phycol. 2017, 29, 255-262. [CrossRef]

17. Varjani, S.; Agarwal, A.K.; Gnansounou, E.; Gurunathan, B. Bioremediation: Applications for Environmental Protection and Management; Springer: Berlin/Heidelberg, Germany, 2018. [CrossRef]

18. Marchello, A.E.; Lombardi, A.T.; Dellamano-Oliveira, M.J.; De Souza, C.W.O. Microalgae population dynamics in photobioreactors with secondary sewage effluent as culture medium. Brazilian J. Microbiol. 2015, 46, 75-84. [CrossRef]

19. Zhu, J.; Rong, J.; Zong, B. Factors in mass cultivation of microalgae for biodiesel. Cuihua Xuebao Chin. J. Catal. 2013, 34, 80-100. [CrossRef]

20. Barsanti, L.; Gualtieri, P. Algae: Anatomy, Biochemistry and Biotechnology. In Climate Change 2013-The Physical Science Basis; CRC Press, Taylor \& Francis Group: Pisa, Italy, 2014; pp. 1-30. [CrossRef]

21. Chen, G.-Q.; Chen, F. Growing Phototrophic Cells without Light. Biotechnol. Lett. 2006, 28, 607-616. [CrossRef]

22. Cheng, L.; Zhang, L.; Chen, H.; Gao, C. Carbon dioxide removal from air by microalgae cultured in a membrane-photobioreactor. Sep. Purif. Technol. 2006, 50, 324-329. [CrossRef]

23. Pal, P.; Chew, K.W.; Yen, H.-W.; Lim, J.W.; Lam, M.K.; Show, P.L. Cultivation of Oily Microalgae for the Production of Third-Generation Biofuels. Sustainability 2019, 11, 5424. [CrossRef]

24. Luo, Y.; Le-Clech, P.; Henderson, R.K. Simultaneous microalgae cultivation and wastewater treatment in submerged membrane photobioreactors: A review. Algal Res. 2017, 24, 425-437. [CrossRef]

25. Gao, F.; Cui, W.; Xu, J.P.; Li, C.; Jin, W.H.; Yang, H.L. Lipid accumulation properties of Chlorella vulgaris and Scenedesmus obliquus in membrane photobioreactor (MPBR) fed with secondary effluent from municipal wastewater treatment plant. Renew. Energy 2019, 136, 671-676. [CrossRef]

26. Quijano, G.; Arcila, J.S.; Buitrón, G. Microalgal-bacterial aggregates: Applications and perspectives for wastewater treatment. Biotechnol. Adv. 2017, 35, 772-781. [CrossRef] [PubMed]

27. Siddeeg, S.M.; Tahoon, M.A.; Ben Rebah, F. Agro-industrial waste materials and wastewater as growth media for microbial bioflocculants production: A review. Mater. Res. Express 2020, 7. [CrossRef]

28. Lavrinovičs, A.; Juhna, T. Review on Challenges and Limitations for Algae-Based Wastewater Treatment. Constr. Sci. 2018, 20, 17-25. [CrossRef]

29. Rawat, I.; Gupta, S.K.; Shriwastav, A.; Singh, P.; Kumari, S.; Bux, F. Microalgae Applications in Wastewater Treatment. Algae Biotechnol. 2016, 249-268. [CrossRef]

30. Herrador, M. The Microalgae/Biomass Industry in Japan -An Assessment of Cooperation and Business Potential With European Companies; EU Japan Centre Industrial Cooperation: Tokyo, Japan, 2016.

31. Nur, M.M.A.; Buma, A.G.J. Opportunities and Challenges of Microalgal Cultivation on Wastewater, with Special Focus on Palm Oil Mill Effluent and the Production of High Value Compounds. Waste Biomass Valorization 2019, 10, 2079-2097. [CrossRef]

32. Chen, Y.; Sun, L.P.; Liu, Z.H.; Martin, G.; Sun, Z. Integration of Waste Valorization for Sustainable Production of Chemicals and Materials via Algal Cultivation. Top. Curr. Chem. 2017, 375. [CrossRef]

33. Satyanarayana, K.G.; Mariano, A.B.; Vargas, J.V.C. A review on microalgae, a versatile source for sustainable energy and materials. Int. J. Energy Res. 2011, 35, 291-311. [CrossRef]

34. Fazal, T.; Mushtaq, A.; Rehman, F.; Ullah Khan, A.; Rashid, N.; Farooq, W.; Rehman, M.S.U.; Xu, J. Bioremediation of textile wastewater and successive biodiesel production using microalgae. Renew. Sustain. Energy Rev. 2018, 82, 3107-3126. [CrossRef] 
35. Nwoba, E.G.; Ayre, J.M.; Moheimani, N.R.; Ubi, B.E.; Ogbonna, J.C. Growth comparison of microalgae in tubular photobioreactor and open pond for treating anaerobic digestion piggery effluent. ALGAL 2016, 17, 268-276. [CrossRef]

36. Padmaperuma, G.; Kapoore, R.V.; Gilmour, D.J.; Vaidyanathan, S. Microbial consortia: A critical look at microalgae co-cultures for enhanced biomanufacturing. Crit. Rev. Biotechnol. 2018, 38, 690-703. [CrossRef] [PubMed]

37. Arora, N.; Patel, A.; Mehtani, J.; Pruthi, P.A.; Pruthi, V.; Poluri, K.M. Co-culturing of oleaginous microalgae and yeast: Paradigm shift towards enhanced lipid productivity. Environ. Sci. Pollut. Res. 2019, 26, 16952-16973. [CrossRef] [PubMed]

38. Magdouli, S.; Brar, S.K.; Blais, J.F. Co-culture for lipid production: Advances and challenges. Biomass Bioenergy 2016, 92, 20-30. [CrossRef]

39. Eroglu, E.; Agarwal, V.; Bradshaw, M.; Chen, X.; Smith, S.M.; Raston, C.L.; Swaminathan Iyer, K. Nitrate removal from liquid effluents using microalgae immobilized on chitosan nanofiber mats. Green Chem. 2012, 14, 2682. [CrossRef]

40. Mallick, N. Biotechnological potential of immobilized algae for wastewater N, P and metal removal: A review. BioMetals 2002, 15, 377-390. [CrossRef] [PubMed]

41. Eriksen, N.T.; Geest, T.; Iversen, J.J.L. Phototrophic growth in the lumostat: A photo-bioreactor with on-line optimization of light intensity. J. Appl. Phycol. 1996, 8, 345-352. [CrossRef]

42. Zohri, A.-N.A.; Ragab, S.W.; Mekawi, M.I.; Mostafa, O.A.A. Comparison between batch, fed-batch, semi-continuous and continuous techniques for bio-ethanol production from a mixture of egyptian cane and beet molasses. Egypt. Sugar J. 2017, 9, 89-111.

43. Ho, S.-H.; Ye, X.; Hasunuma, T.; Chang, J.-S.; Kondo, A. Perspectives on engineering strategies for improving biofuel production from microalgae-A critical review. Biotechnol. Adv. 2014, 32, 1448-1459. [CrossRef]

44. Sforza, E.; Enzo, M.; Bertucco, A. Design of microalgal biomass production in a continuous photobioreactor: An integrated experimental and modeling approach. Chem. Eng. Res. Des. 2014, 92, 1153-1162. [CrossRef]

45. Ravindran, B.; Gupta, S.K.; Cho, W.M.; Kim, J.K.; Lee, S.R.; Jeong, K.H.; Lee, D.J.; Choi, H.C. Microalgae potential and multiple roles-current progress and future prospects-an overview. Sustainability 2016, 8, 1215. [CrossRef]

46. Enamala, M.K.; Enamala, S.; Chavali, M.; Donepudi, J.; Yadavalli, R.; Kolapalli, B.; Aradhyula, T.V.; Velpuri, J.; Kuppam, C. Production of biofuels from microalgae-A review on cultivation, harvesting, lipid extraction, and numerous applications of microalgae. Renew. Sustain. Energy Rev. 2018, 94, 49-68. [CrossRef]

47. Koreiviene, J.; Paskauskas, R. EU Project of LIFE Programme 'Algae Service for LIFE' Develops Ecologicaly Sustainable Bioproducts from Freshwater Cyanobacteria and Macroalgae Biomass. Botanica 2019, 25, 176-185. [CrossRef]

48. Börner, K.; Chen, C.; Boyack, K.W. Visualizing knowledge domains. Annu. Rev. Inf. Sci. Technol. 2005, 37, 179-255. [CrossRef]

49. Cobo, M.J.; López-Herrera, A.G.; Herrera-Viedma, E.; Herrera, F. SciMAT: A new science mapping analysis software tool. J. Am. Soc. Inf. Sci. Technol. 2012, 63, 1609-1630. [CrossRef]

50. Herrera-Viedma, E.; Martinez, M.A.; Herrera, M. Bibliometric Tools for Discovering Information in Database. In Lecture Notes in Computer Science (including subseries Lecture Notes in Artificial Intelligence and Lecture Notes in Bioinformatics); Springer Verlag: Berlin/Heidelberg, Germany, 2016; Volume 9799, pp. 193-203. [CrossRef]

51. López-Robles, J.R.; Otegi-Olaso, J.R.; Porto Gómez, I.; Cobo, M.J. 30 years of intelligence models in management and business: A bibliometric review. Int. J. Inf. Manag. 2019, 48, 22-38. [CrossRef]

52. Lee, E.; Jalalizadeh, M.; Zhang, Q. Growth kinetic models for microalgae cultivation: A review. Algal Res. 2015, 12, 497-512. [CrossRef]

53. Martínez, M.E.; Sánchez, S.; Jiménez, J.M.; El Yousfi, F.; Muñoz, L. Nitrogen and phosphorus removal from urban wastewater by the microalga Scenedesmus obliquus. Bioresour. Technol. 2000, 73, 263-272. [CrossRef]

54. Klekner, V.; Kosaric, N. Degradation of phenols by algae. Environ. Technol. (UK) 1992, 13, 493-501. [CrossRef]

55. Ellis, B.E. Degradation of phenolic compounds by fresh-water algae. Plant. Sci. Lett. 1977, 8, $213-216$. [CrossRef]

56. Scragg, A.H. The effect of phenol on the growth of Chlorella vulgaris and Chlorella VT-1. Enzyme Microb. Technol. 2006, 39, 796-799. [CrossRef] 
57. Mahan, C.A.; Majidi, V.; Holcombe, J.A. Evaluation of the metal uptake of several algae strains in a multicomponent matrix utilizing inductively coupled plasma emission spectrometry. Anal. Chem. 1989, 61, 624-627. [CrossRef] [PubMed]

58. Suresh Kumar, K.; Dahms, H.U.; Won, E.J.; Lee, J.S.; Shin, K.H. Microalgae-A promising tool for heavy metal remediation. Ecotoxicol. Environ. Saf. 2015, 113, 329-352. [CrossRef]

59. De Schryver, P.; Crab, R.; Defoirdt, T.; Boon, N.; Verstraete, W. The basics of bio-flocs technology: The added value for aquaculture. Aquaculture 2008, 277, 125-137. [CrossRef]

60. Lee, J.; Cho, D.H.; Ramanan, R.; Kim, B.H.; Oh, H.M.; Kim, H.S. Microalgae-associated bacteria play a key role in the flocculation of Chlorella vulgaris. Bioresour. Technol. 2013, 131, 195-201. [CrossRef] [PubMed]

61. Heydarizadeh, P.; Boureba, W.; Zahedi, M.; Huang, B.; Moreau, B.; Lukomska, E.; Couzinet-Mossion, A.; Wielgosz-Collin, G.; Martin-Jézéquel, V.; Bougaran, G. Response of $\mathrm{CO}_{2}$-starved diatom Phaeodactylum tricornutum to light intensity transition. Philos. Trans. R. Soc. B Biol. Sci. 2017, 372. [CrossRef]

62. Salim, S.; Bosma, R.; Vermuë, M.H.; Wijffels, R.H. Harvesting of microalgae by bio-flocculation. J. Appl. Phycol. 2011, 23, 849-855. [CrossRef]

63. Xiong, J.Q.; Kurade, M.B.; Abou-Shanab, R.A.I.; Ji, M.K.; Choi, J.; Kim, J.O.; Jeon, B.H. Biodegradation of carbamazepine using freshwater microalgae Chlamydomonas mexicana and Scenedesmus obliquus and the determination of its metabolic fate. Bioresour. Technol. 2016, 205, 183-190. [CrossRef]

64. Santos, C.E.; de Coimbra, R.N.; Bermejo, S.P.; Pérez, A.I.G.; Cabero, M.O. Comparative Assessment of Pharmaceutical Removal from Wastewater by the Microalgae Chlorella sorokiniana, Chlorella vulgaris and Scenedesmus obliquus. In Biological Wastewater Treatment and Resource Recovery; InTech: London, UK, 2017. [CrossRef]

65. Kumar, K.; Mishra, S.K.; Shrivastav, A.; Park, M.S.; Yang, J.-W. Recent trends in the mass cultivation of algae in raceway ponds. Renew. Sustain. Energy Rev. 2015, 51, 875-885. [CrossRef]

66. Gupta, P.L.; Lee, S.M.; Choi, H.J. A mini review: Photobioreactors for large scale algal cultivation. World J. Microbiol. Biotechnol. 2015, 31, 1409-1417. [CrossRef]

67. Wang, J.H.; Zhuang, L.L.; Xu, X.Q.; Deantes-Espinosa, V.M.; Wang, X.X.; Hu, H.Y. Microalgal attachment and attached systems for biomass production and wastewater treatment. Renew. Sustain. Energy Rev. 2018, 92, 331-342. [CrossRef]

68. Shi, J.; Podola, B.; Melkonian, M. Removal of nitrogen and phosphorus from wastewater using microalgae immobilized on twin layers: An experimental study. J. Appl. Phycol. 2007, 19, 417-423. [CrossRef]

69. Derakhshan, Z.; Ehrampoush, M.H.; Mahvi, A.H.; Dehghani, M.; Faramarzian, M.; Eslami, H. A comparative study of hybrid membrane photobioreactor and membrane photobioreactor for simultaneous biological removal of atrazine and CNP from wastewater: A performance analysis and modeling. Chem. Eng. J. 2019, 355, 428-438. [CrossRef]

70. Cobo, M.J.; López-Herrera, A.G.; Herrera-Viedma, E.; Herrera, F. An approach for detecting, quantifying, and visualizing the evolution of a research field: A practical application to the Fuzzy Sets Theory field. J. Informetr. 2011, 5, 146-166. [CrossRef]

71. Edwards, P.; Sinchumpasak, O.A.; Tabucanon, M. The harvest of microalgae from the effluent of a sewage fed high rate stabilization pond by Tilapia nilotica. Part 2: Studies of the fish ponds. Aquaculture 1981, 23, 107-147. [CrossRef]

72. Edwards, P.; Sinchumpasak, O.A. The harvest of microalgae from the effluent of a sewage fed high rate stabilization pond by Tilapia nilotica. Part 1: Description of the system and the study of the high rate pond. Aquaculture 1981, 23, 83-105. [CrossRef]

73. Edwards, P.; Sinchumpasak, O.A.; Labhsetwar, V.K.; Tabucanon, M. The harvest of microalgae from the effluent of a sewagefed high rate stabilization pond by Tilapia nilotica. Part 3: Maize cultivation experiment, bacteriological studies, and economic assessment. Aquaculture 1981, 23, 149-170. [CrossRef]

74. Sheehan, J.; Dunahay, T.; Benemann, J.; Roessler, P.; Dunahay, T.; Benemann, J.; Roessler, P. A Look Back at the U.S. Department of Energy's Aquatic Species Program-Biodiesel from Algae; National Renewable Energy Laboratory: Golden, CO, USA, 1998. [CrossRef]

75. James, C.M.; Al-Khars, A.M. An intensive continuous culture system using tubular photobioreactors for producing microalgae. Aquaculture 1990, 87, 381-393. [CrossRef]

76. Familletti, P.C. Air Lift Bioreactor. U. S. Patent 4,649,117, 10 March 1987. 
77. Armstrong, D.W.; Ottawa, L.; Fleming, P.; Grenzowski, D. Cell Culture Bioreactor. U.S. Patent 4,906,577, 6 March 1990.

78. Raymond, L.P. Mass Algal Culture System. U. S. Patent 4,253,271, 3 March 1981.

79. Jais, N.M.; Mohamed, R.M.S.R.; Al-Gheethi, A.A.; Hashim, M.K.A. The dual roles of phycoremediation of wet market wastewater for nutrients and heavy metals removal and microalgae biomass production. Clean Technol. Environ. Policy. 2017, 19, 37-52. [CrossRef]

80. AlMomani, F.A.; Örmeci, B. Performance Of Chlorella Vulgaris, Neochloris Oleoabundans, and mixed indigenous microalgae for treatment of primary effluent, secondary effluent and centrate. Ecol. Eng. 2016, 95, 280-289. [CrossRef]

81. Goncalves, E.C.; Wilkie, A.C.; Kirst, M.; Rathinasabapathi, B. Metabolic regulation of triacylglycerol accumulation in the green algae: Identification of potential targets for engineering to improve oil yield. Plant. Biotechnol. J. 2016, 14, 1649-1660. [CrossRef]

82. Çetinkaya Dönmez, G.; Aksu, Z.; Öztürk, A.; Kutsal, T. A comparative study on heavy metal biosorption characteristics of some algae. Process. Biochem. 1999, 34, 885-892. [CrossRef]

83. Matsunaga, T.; Takeyama, H.; Nakao, T.; Yamazawa, A. Screening of marine microalgae for bioremediation of cadmium-polluted seawater. J. Biotechnol. 1999, 70, 33-38. [CrossRef]

84. Acién Fernández, F.G.; Gómez-Serrano, C.; Fernández-Sevilla, J.M. Recovery of Nutrients From Wastewaters Using Microalgae. Front. Sustain. Food Syst. 2018, 2, 1-13. [CrossRef]

85. Chen, F.; Johns, M.R. Heterotrophic growth of Chlamydomonas reinhardtii on acetate in chemostat culture. Process. Biochem. 1996, 31, 601-604. [CrossRef]

86. Ruxton, C.; Reed, S.; Simpson, M.; Millington, K. The health benefits of omega-3 polyunsaturated fatty acids: A review of the evidence. Discovery Service for Endeavour College of Natural Health Library. J. Hum. Nutr. Diet. 2004, 20, 275-285. [CrossRef]

87. Giger, W. Hydrophilic and amphiphilic water pollutants: Using advanced analytical methods for classic and emerging contaminants. Anal. Bioanal. Chem. 2009, 393, 37-44. [CrossRef]

88. Boxall, A.B.A. New and Emerging Water Pollutants arising from Agriculture; OECD: Paris, France, 2012.

89. Dulio, V.; Assoumani, A. Contaminants of Emerging Concern in Urban Wastewater; Position Paper to the Workshop on Prioritisation of Emerging Contaminants in Urban Wastewater; Norman: Paris, France, 2019.

90. Pereira, S.A.; Araújo, V.Q.; Reboucas, M.V.; Vieira, F.S.V.; De Almeida, M.V.A.; Chinalia, F.A.; Nascimento, I.A. Toxicity of biodiesel, diesel and biodiesel/diesel blends: Comparative sub-lethal effects of water-soluble fractions to microalgae species. Bull. Environ. Contam. Toxicol. 2012, 88, 234-238. [CrossRef]

91. Asselborn, V.; Fernández, C.; Zalocar, Y.; Parodi, E.R. Effects of chlorpyrifos on the growth and ultrastructure of green algae, Ankistrodesmus gracilis. Ecotoxicol. Environ. Saf. 2015, 120, 334-341. [CrossRef]

92. Chung, M.K.; Hu, R.; Wong, M.H.; Cheung, K.C. Comparative toxicity of hydrophobic contaminants to microalgae and higher plants. Ecotoxicology 2007, 16, 393-402. [CrossRef]

93. Posadas, E.; Serejo, M.L.; Blanco, S.; Pérez, R.; García-Encina, P.A.; Muñoz, R. Minimization of biomethane oxygen concentration during biogas upgrading in algal-bacterial photobioreactors. Algal Res. 2015, 12, 221-229. [CrossRef]

94. Halim, R.; Danquah, M.K.; Webley, P.A. Extraction of oil from microalgae for biodiesel production: A review. Biotechnol. Adv. 2012, 30, 709-732. [CrossRef] [PubMed]

95. Biological Processing of Agricultural and Food Wastes to Recover Energy, Nutrients and Water for Sustainable Agricultural Production-North Carolina A\&T State University. Available online: https://reeis.usda.gov/web/crisprojectpages/1003263-biological-processing-of-agricultural-and-foodwastes-to-recover-energy-nutrients-and-water-for-sustainable-agricultural-production.html (accessed on 13 January 2020).

(C) 2020 by the authors. Licensee MDPI, Basel, Switzerland. This article is an open access article distributed under the terms and conditions of the Creative Commons Attribution (CC BY) license (http://creativecommons.org/licenses/by/4.0/). 